\title{
Clinical registry of cardiovascular surgeries in a university hospital
}

\author{
Roberta Senger ${ }^{\mathbf{1}}$ \\ Michelle Dornelles Santarem ${ }^{2}$ \\ Silvia Goldmeier ${ }^{3}$
}

\begin{abstract}
1. Santa Maria University Hospital - Santa Maria - RS, Brasil 2. Clinical Hospital of Porto Alegre, Brasil. Post-Graduate Program Research and Innovation Processes in Health, Cardiology Institute of the University Foundation of Cardiology - Porto Alegre - RS, Brasil 3. Post-Graduate Program Research and Innovation Processes in Health, Cardiology Institute of the University Foundation of Cardiology - Porto Alegre - RS, Brasil
\end{abstract}

http://dx.doi.org/10.1590/1806-9282.65.1.16

\section{SUMMARY}

OBJECTIVES: To create and implement a computerized clinical registry to verify in the short-, medium- and long-term the mortality and the incidence of significant surgical outcomes in adult patients submitted to cardiovascular surgeries.

METHODS: This is a prospective, observational registry-based study aimed at documenting the characteristics of patients undergoing cardiovascular surgery.

RESULTS: Variables were standardized according to international references from the Society of Thoracic Surgeons (STS), American College of Cardiology (ACC), Michigan Society of Thoracic and Cardiovascular Surgeons (MSTCVS) and the Department of Informatics of SUS (DATASUS). The standardization was performed in English with an interface in Portuguese to make the data collection easier in the institution. Quality of care indicators, surgical procedure characteristics, in addition to significant cardiovascular outcomes will be measured. Data were collected during the hospitalization until hospital discharge or at the seventh day, in thirty days, six months, twelve months and annually until completing five years.

CONCLUSION: The importance of a database maintenance with international standards that can be reproducible was evidenced, allowing the evaluation of techniques and assistance and the integration of data among health institutions.

KEYWORDS: Cardiovascular surgical procedures. Database. Electronic health records.

\section{INTRODUCTION}

Cardiovascular diseases (CVD) are the leading causes of mortality in Brasil and in the world. In $2003,32 \%$ of $69 \%$ of the well-defined deaths in Brasil were due to $\mathrm{CVD}^{1}$. According to the World Health Organization $(\mathrm{WHO})^{2}$, in 2030, 23.6 million people will die from CVD. Factors related to CVD can be of biological and/or behavioral nature ${ }^{3}$.

Surgery is one of the therapeutic options. In Brasil, 63,529 heart surgeries were performed between 2005 and 2007; while in 2011, they went up to 100,000 , showing a significant increase in the number of these procedures. There are 170 centers all over Brasil, with more than 1,000 surgeons associated with the Brazilian Society of Cardiovascular Surgery ${ }^{4,5}$.

Despite the high direct and indirect costs, there are few sources of information with high-quality data collected systematically to monitor the procedures and outcomes of these patients. There is no system to monitor adverse events of cardiovascular surger-

DATE OF SUBMISSION: 01-Oct-2018

DATE OF ACCEPTANCE: 16-Oct-2018

CORRESPONDING AUTHOR: Silvia Goldmeier

Cardiology Institute / University Foundation of Cardiology, Porto Alegre

Avenida Princesa Isabel, 370, $3^{\circ}$ andar, Bairro Santana, Porto Alegre, RS, Brasil - CEP 99620-000

Fax: +55 5132354127

E-mail: silvia.gold@cardiologia.org.br

betasng@gmail.com michesantarem@gmail.com pesquisa.sgold@gmail.com 
ies following international quality standards yet. The registries started to be used in the clinical practice due to the need of using clinical and evolution history of these patients ${ }^{6}$. A high-quality medical record helps to monitor and improve the patients' health, describing the epidemiological and clinical characteristics of the diseases and the assessment of the interventions ${ }^{7}$.

Electronic technology improved the registry and facilitated the communication between doctors and patients, among health providers, and the access to medical information ${ }^{8}$. Barriers like costs, inappropriate medical information, lack of standards, patient privacy, knowledge, and data management still need to be surpassed ${ }^{9,10}$.

Electronic databases are not adopted in several medical and academic centers yet ${ }^{11}$. The use of validated data collection tools and forms based on standards make it easier to visualize and share these data, as well to participate in multicentric studies ${ }^{12}$.

REDCap (Research Electronic Data Capture) is a web-based software solution with tools that reliably create online forms to capture, manage and analyze data during the process of investigation ${ }^{13}$. REDCap allows data to be collected in an offline environment and synchronized in the REDCap server when it is connected to the Internet ${ }^{14,15}$. Our aim was to create and implement a computerized clinical record.

\section{METHODS}

\section{Study design}

A prospective, observational registry-based study, aimed to record cardiovascular variables, surgical procedures and extracorporeal circulation (ECC), as well as the clinical evolution. The longitudinal follow-up of the patients will happen from the moment of the procedure until hospital discharge, at thirty days, six months, twelve months and annually until completing five years.

\section{Sample/target population}

Adult patients submitted to cardiovascular surgery in Santa Maria University Hospital (SMUH).

\section{Inclusion criteria}

Patients who are 18-years-old or older from both sexes, suffering from cardiovascular disease and submitted to the following surgeries will be included:
- Myocardial revascularization surgery

- Valve surgery

- Aorta surgery

- Surgical correction of congenital disease in the adult

\section{Outcomes of interest}

Mortality from all causes and cardiovascular events (reinfarction, stroke, fatal and non-fatal cardiac arrest, and mortality for cardiovascular cause) during the hospitalization and up to thirty days, six months, twelve months and annually until completing five years.

\section{Ethical aspects}

The clinical study described in this paper was conducted under the principles of the current revision of the Declaration of Helsinki and the most recent version of the Guideline for Good Clinical Practice (ICH-GCP), as well as the Resolution 466/12. The study was developed in compliance with Brazilian legal and regulatory requirements.

The names of all participants were kept as confidential. They were identified in the documentation and during the evaluation by the number assigned to each one in the study. It was guaranteed to the patients that all the findings were stored in computers and handled according to the strictest rules of confidentiality. All the data collected and stored in the registry were screened. This screening will have the function of guaranteeing that no patient identification data will be shown in the final version of the registry, following international requirements for privacy of clinical data. The de-identification of the database is made through the transformation of all the dates in intervals with reference to a random date randomly selected and stored by the individual responsible for the data management. Geolocalization data were modified to respect the national and international data safety rules. For storage in Research Ethics Committees (REC), only the three initial digits will be kept, following HIPAA (Health Insurance Portability and Accountability Act) rules. However, as the Brazilian rules do not require the storage of REC 3 digits only, a secondary bank with five digits was kept in our server, protected for the exclusive use of computers with a national internet protocol (IP) address.

The study was submitted and approved by the Education and Research Department of SMUH under 
the number 046/2016 and by the REC of the Institute of Cardiology/University Foundation of Cardiology (ICUFC) under the UP number 5017/14. All the patients who will participate in the study will sign the Consent Form (CF).

\section{Risks and benefits}

There will be no any additional risks to the patients neither to the institution due to inclusion in this study, considering that this is an observational registry-based study. Therefore, it does not submit the patients to any intervention that is not correctly

indicated and implemented by the assistant doctor, in his/her usual clinical practice procedures. There will be no additional costs or discomfort to the patients.

\section{RESULTS}

The outcomes of the development and implementation of the CardioCEC clinical registry will be shown in steps (Figure 1).

\section{Creation of the CardioCEC clinical registry}

Given the need to monitor the high number of high-cost procedures and to evaluate the outcomes of these patients in SMUH, we decided to create and develop an information source with data collected in a systematized and high-quality way.

\section{Software}

We used the REDCap (Research Electronic Data Capture) software for collection and storage of the research data. Data were physically stored in a server located in ICUFC, in the department of informatics of the institution and protected by the firewall of the ICUFC network and the REDCap access permission system itself (Figure 2). The infrastructure requirements, such as a web server that offers support to PHP, a MySQL database server and Secure Sockets Layer (SSL) connections, need to be present (http:// project-redcap.org/).

\section{Variables standardization}

Initially, the variables and the standardization of the nomenclatures were defined in order to guarantee that the data input into the registry was compatible with international databases. The variable standardization was followed international references from the American College of Cardiology Foundation
(ACCF), the American Heart Association (AHA), the Society of Thoracic Surgeon (STS), The Michigan Society of Thoracic and Cardiovascular Surgeons (MSTCVS) and the SUS Department of Informatics DATASUS. International scope variables that are usually used for the connection with vast repositories of global databases were included. The standardization was made in English, and an interface in Portuguese was implemented to make the data collection easier in the institution.

\section{Inclusion of variables}

The CardioCEC database has 553 variables distributed in 12 data collection tools, standardized according to international references, allowing for the participation in multicentric studies (Table 1).

\section{Data collection logistics}

The data collection of the patients will be made by a skilled team engaged in the procedure (CRF, case report forms). The CardioCEC Clinical Registry will be accomplished through internet and intranet access through any computer of the hospitalization units, or the thoracic surgery room, or through the REDCap app, and all the information collected will be input into the system.

All the patients who meet the eligibility criteria will have their data collected following the CF signature. The data of the patients will be filled out in the clinical chart preferably in the day previous to the surgery (demographic data and admission, preoperative). The surgical procedure (intraoperative) will be informed in the period following the discharge from the intensive care unit (ICU discharge). The prospective data will be informed until the hospital discharge or up to seven days. The clinical follow-up chart of 30 days, six months and 12 months, as well as the annual follow-up, will always be filled out within seven days. The hard outcomes will be obtained through the medical record or a telephone call to the patient, family member or third party.

The team may collect information on the patient's mortality and major cardiovascular events through a telephone call to the patient, a family member or a third party, or from the patient's medical record.

\section{Bias prevention}

It is essential to have a mechanism to reduce the possibility of data entry errors. With REDCap, we restricted the format/type of data and established inter- 


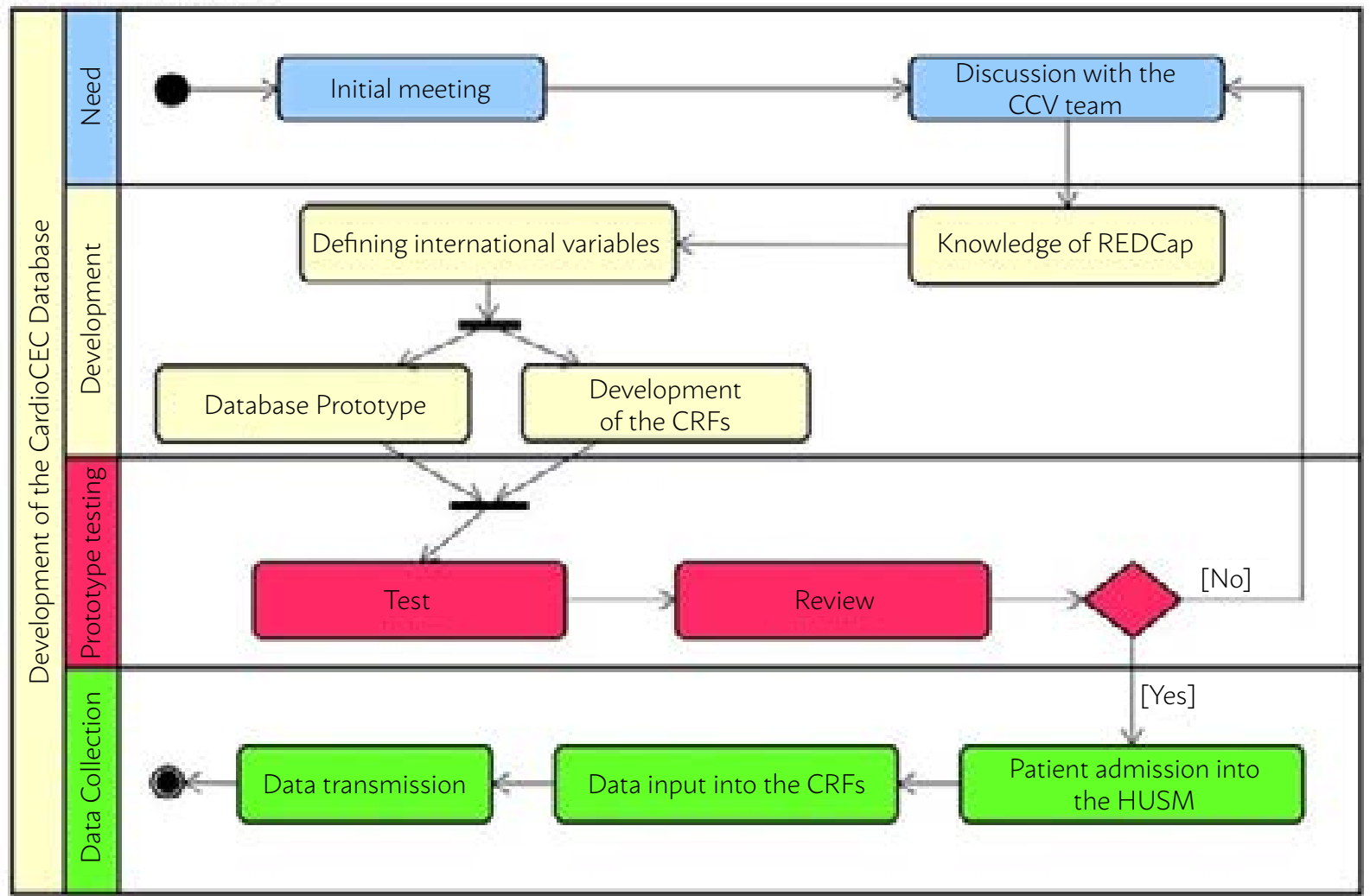

FIGURE 2: REDCAP SOFTWARE FOR THE CONSTRUCTION OF THE CARDIOCEC CLINICAL REGISTRY.

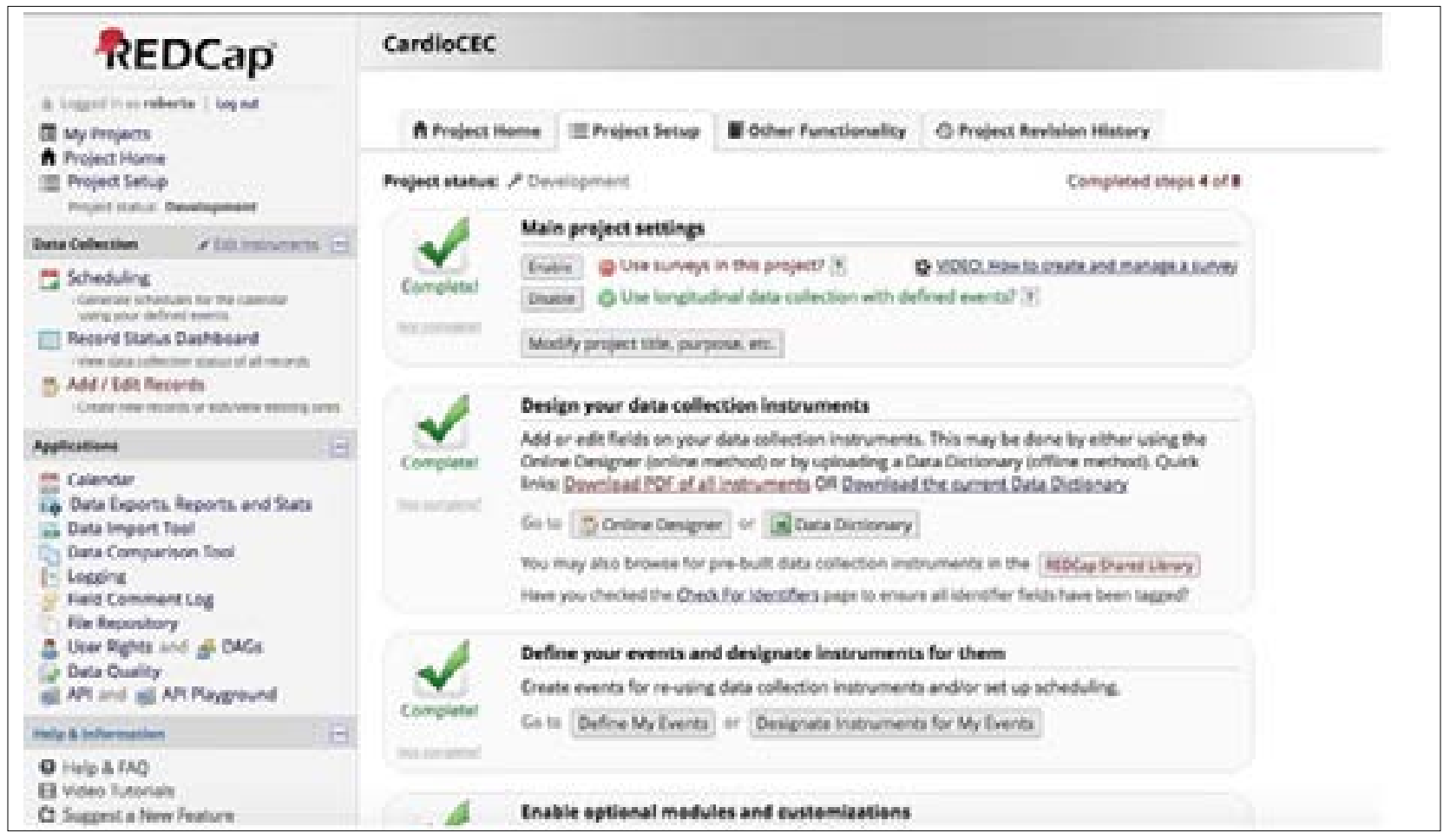


TABLE 1: VARIABLE STANDARDIZATION

\begin{tabular}{|c|c|c|}
\hline $\begin{array}{l}\text { Name of the instru- } \\
\text { ment }\end{array}$ & Variables & $\begin{array}{l}\text { Source of standard- } \\
\text { ization }\end{array}$ \\
\hline $\begin{array}{l}\text { Demographic data - } \\
\text { Admission }\end{array}$ & $\begin{array}{l}\text { Record ID, Date of admission, Form of admission, Last name, Name, Middle name, Number of the } \\
\text { National Health Card (CNS), SAME, Date of birth, Age, Race, Gender, Address, City }\end{array}$ & DATASUS, IBGE, STS \\
\hline $\begin{array}{l}\text { Preoperative risk fac- } \\
\text { tors, Preoperative heart } \\
\text { status, Preoperative } \\
\text { drugs }\end{array}$ & $\begin{array}{l}\text { Record ID, Weight, Height, BMI, Smoker, Current smoker, Diabetes, Diabetes control, Dyslipidemia, } \\
\text { Dyslipidemia control, Kidney failure, Dialysis, Hypertension, Stroke, Time since stroke, Infectious en- } \\
\text { docarditis, Type of endocarditis, Pulmonary disease, Immunosuppressing therapy, Peripheral vascular } \\
\text { disease, Cerebrovascular disease, AMI, Time AMI, Heart failure last } 2 \text { weeks, CHF, Heart condition at } \\
\text { admission, Cardiogenic shock, Cardiac resuscitation, Arrhythmia, Type of arrhythmia, NYHA, Beta } \\
\text { blockers, Use of BB } 2 \text { weeks, ACE-inhibitor, Nitrates, Anticoagulation, Name anticoagulant, Warfarin, } \\
\text { IV Inotropes, Corticoids, Aspirin, Adenosine diphosphate (ADP) receptor inhibitors, Adenosine diphos- } \\
\text { phate (ADP) receptor inhibitors } 24 \text { hours before, Glycoprotein IIb/IIla, Number of compromised vases, } \\
\text { Percentage main stenosis left side vase, EF measure, EF, Presence of valvopathy, Aortic failure, Aortic } \\
\text { stenosis, Mitral failure, Mitral stenosis, Tricuspid failure, Pulmonary failure, Incidence of surgery, Status, } \\
\text { IABP, Ht, Hb, Na, K, Urea, Creatinine, Glucose, Platelets, TP, TTPA }\end{array}$ & ACCF, NCDR, STS \\
\hline \multirow[t]{2}{*}{ Intraoperative } & $\begin{array}{l}\text { Record ID, Name of surgeon, Surgery category, Use of robotic technology, Minimally invasive pro- } \\
\text { cedure, Conversion to standard procedure, Use of ECC, Use of arterial filter, Strategy of acid-base } \\
\text { management, Bioactive coating area, Type of system, Assistance in venous draining, Type of arterial } \\
\text { pump, Use of autotransfusion Pulsatile Perfusion device, Saline solution filling volume, Ringer lactate } \\
\text { filling volume, Plasma-Lyte filling volume, Albumin } 5 \% \text { filling volume, Albumin } 25 \% \text { filling volume, } \\
\text { Starch solution filling volume, Mannitol filling volume, Sodium bicarbonate filling volume, Red cells } \\
\text { concentrates in priming, Plasma in priming, Heparin dose, Total volume of priming, Time of perfusion, } \\
\text { Type of aorta clamping, Site of aorta clamping, Time of aorta occlusion or clamping, Circulatory arrest } \\
\text { (CA), Time of CA, Selective cerebral perfusion (SCP), Time of SCP, Time of reperfusion, Return to ECC, } \\
\text { Reasons for returning to ECC, Cardioplegia, Type of cardioplegia, Regimen of cardioplegia, Tempera- } \\
\text { ture of cardioplegia induction, Direction of cardioplegia induction flow, Temperature of cardioplegia } \\
\text { maintenance, Direction of cardioplegia maintenance flow, Total volume of cardioplegia, Assessment of } \\
\text { the presence of preexistent calcifications in the site of aorta handling, Aorta classification, Site of tem- } \\
\text { perature measurement, Lower temperature reached in the nasopharyngeal path, Lower temperature } \\
\text { reached in the esophageal path, Lower temperature reached in the jugular bulb region }\end{array}$ & STS, PERForm \\
\hline & $\begin{array}{l}\text { Lower temperature reached in the rectal path, Lower tympanic temperature reached, Lower tempera- } \\
\text { ture reached in other paths, Higher temperature reached in the nasopharyngeal path, Higher tempera- } \\
\text { ture reached in the esophageal path, Higher temperature reached in the jugular bulb region, Higher } \\
\text { temperature reached in the rectal path, Higher tympanic temperature reached, Higher temperature } \\
\text { reached in other paths, Temperature following ECC, Initial Hematocrit (Ht) in ECC, Initial hemoglobin } \\
\text { (Hb) in ECC, Hematocrit (Ht) when leaving the surgery room, Hemoglobin (Hb) when leaving the } \\
\text { surgery room, Intra-Aortic Balloon Pump (IABP) in the surgery room, Period of insertion of IABP in } \\
\text { the surgery room, Indication of IABP in the surgery room, Use of hemoderivatives, Use of red cells } \\
\text { concentrate, Use of fresh frozen plasma, Use of platelets, Use of cryoprecipitate, Fibrinogen concentrate } \\
\text { was administered, Prothrombin complex concentrate was administered, Administered dose of fibrino- } \\
\text { gen concentrate, Administered dose of prothrombin complex concentrate, Volume of SS O.9\% used in } \\
\text { ECC, Volume of Ringer lactate used in ECC, Volume of Plasma-Lyte used in ECC, Volume of Albumin } \\
5 \% \text { used in ECC, Volume of Albumin } 25 \% \text { used in ECC, Volume of Starch Solution used in ECC, Use } \\
\text { of UF, Total UF volume, Volume of residual blood that returned to the patient, Volume of urine in the } \\
\text { intraoperative period Presence of hemoglobin, Inotropic in use in the transfer to the ICU, Myocardial } \\
\text { revascularization surgery } \\
\text { Number of distal anastomoses with arterial graft, Number of distal anastomoses with venous graft, } \\
\text { Number of distal anastomoses with internal mammary artery graft, Number of distal anastomoses } \\
\text { with radial artery graft, Number of distal anastomoses with Gastroepiploic artery graft, Number of } \\
\text { anastomoses with other arterial grafts, Procedure in the aortic valve, Procedure in the mitral valve, } \\
\text { Procedure in the tricuspid valve, Procedure in the pulmonary valve, Correction of aorta aneurysm, sur- } \\
\text { gery of congenital cardiopathy, Surgery of aorta dissection correction, Other cardiovascular surgeries, } \\
\text { Extubation in the surgery room }\end{array}$ & \\
\hline \multirow[t]{2}{*}{ ICU discharge } & $\begin{array}{l}\text { Record ID } \\
\text { Date and time of entrance at ICU, Date and time of discharge from ICU, Reintubation, Additional hours } \\
\text { in MV, Total hours in MV, creatinine, hemoderivatives, units of red blood concentrate, Units of fresh } \\
\text { frozen plasma, units of platelets, units of cryoprecipitate, Hematocrit at discharge, Hemoglobin at } \\
\text { discharge, Echocardiogram, Presence of aortic valve failure, Presence of mitral valve failure, Presence of } \\
\text { tricuspid valve failure, Presence of pulmonary valve failure, EF, Cardiac enzymes, Higher CKMB value } \\
\text { measured, Higher Troponin value measured, Higher Troponin T value measured, ECG result, surgical } \\
\text { intervention, Reintervention for bleeding, Date of intervention for bleeding, Intervention for valve } \\
\text { dysfunction, Reintervention for coronary occlusion, Reintervention for other cardiac reasons, Reinter- } \\
\text { vention for other non-cardiac reasons, complication in PO, Deep infection of the sternum, Infection of } \\
\text { thoracotomy, Infection of OW in the site of grafts removal, Sepsis, Stroke, TIS, Prolonged mechanical } \\
\text { ventilation (MV), Pneumonia, Infection in the urinary tract, Kidney failure, Dialysis, Deep vein thrombo- } \\
\text { sis (DVT), Pulmonary thromboembolism }\end{array}$ & $\begin{array}{l}\text { ACCF, NCDR, STS, } \\
\text { PERForm }\end{array}$ \\
\hline & $\begin{array}{l}\text { Limb ischemia, Myocardial infarction, Rhythm dysfunction requiring device, PCR, Events related to } \\
\text { anticoagulant therapy, GI, Dysfunction of multiple organs, Atrial fibrillation / flutter, Injury of the } \\
\text { laryngeal nerve, Injury of the phrenic nerve, Other events, Identification of the event, ACE-inhibitor, } \\
\text { Beta blockers, Nitrates, Anticoagulants, Name of anticoagulant, Warfarin, IV Inotropes, Corticoids, } \\
\text { Acetylsalicylic acid, Adenosine diphosphate (ADP) receptor inhibitors, Glycoprotein IIb/IIla }\end{array}$ & \\
\hline
\end{tabular}




\begin{tabular}{|c|c|c|}
\hline $\begin{array}{l}\text { Name of the instru- } \\
\text { ment }\end{array}$ & Variables & $\begin{array}{l}\text { Source of standard- } \\
\text { ization }\end{array}$ \\
\hline Hospital discharge & $\begin{array}{l}\text { Patient status, Date and time of the hospital discharge, Date and time of death, Cause of death, } \\
\text { Units of red cell concentrate, Units of fresh frozen plasma, Units of platelets, Units of Cryoprecipitate, } \\
\text { Echocardiogram, Presence of aortic valve failure, Presence of mitral valve failure, Presence of tricuspid } \\
\text { valve failure, Presence of pulmonary valve failure, EF, PO complications, Deep infection of the sternum, } \\
\text { Infection of the thoracotomy, Infection of the OW in the site of the grafts removal, Sepsis, stroke, TIS, } \\
\text { Prolonged mechanical ventilation (MV), Pneumonia, Infection in the urinary tract, Kidney failure, Dial- } \\
\text { ysis, Deep vein thrombosis (DVT), Pulmonary thromboembolism, Limb ischemia, myocardial infarction, } \\
\text { Rhythm dysfunction requiring device, PCR, Events related to anticoagulant therapy, Gl, Dysfunction } \\
\text { of multiple organs, Atrial fibrillation / flutter, Injury of the laryngeal nerve, Injury of the phrenic nerve, } \\
\text { Other events, Identification of the event, ACE-inhibitor, Beta blockers, Nitrates, Anticoagulants, Name } \\
\text { of the anticoagulant, Warfarin, IV Inotropes, Corticoids, Acetylsalicylic acid, Adenosine diphosphate } \\
\text { (ADP) receptor inhibitors, Glycoprotein IIb/IIla }\end{array}$ & $\begin{array}{l}\text { ACCF, NCDR, STS, } \\
\text { PERForm }\end{array}$ \\
\hline $\begin{array}{l}\text { Follow-up } \\
\text { One month } \\
\text { Six months } \\
\text { One year } \\
\text { Two years } \\
\text { Three years } \\
\text { Four years } \\
\text { Five years }\end{array}$ & $\begin{array}{l}\text { Patient status, Date of hospital discharge, Hospitalization, Still hospitalized, Days of permanence in the } \\
\text { ICU, Date and time of death, Cause of death, Complications, Deep infection of the sternum, Infection } \\
\text { of the thoracotomy, Infection of the OW in the site of the grafts removal, Sepsis, stroke, TIS, Prolonged } \\
\text { mechanical ventilation (MV), Pneumonia, Infection in the urinary tract, Kidney failure, Dialysis, Deep } \\
\text { vein thrombosis (DVT), Pulmonary thromboembolism, Limb ischemia, myocardial infarction, Rhythm } \\
\text { dysfunction requiring device, PCR, Events related to anticoagulant therapy, GI, Dysfunction of multiple } \\
\text { organs, Atrial fibrillation / flutter, Injury of the laryngeal nerve, Injury of the phrenic nerve, Other } \\
\text { events, Identification of the event, ACE-inhibitor, Beta blockers, Nitrates, Anticoagulants, Name of } \\
\text { the anticoagulant, Warfarin, IV Inotropes, Corticoids, Acetylsalicylic acid, Adenosine diphosphate (ADP) } \\
\text { receptor inhibitors, Glycoprotein IIb/IIla }\end{array}$ & $\begin{array}{l}\text { ACCF, NCDR, STS, } \\
\text { PERForm }\end{array}$ \\
\hline
\end{tabular}

vals for numerical and date fields, thus allowing data validation. Problems with data consistency, like the wrong types of data, out of reach values and outliers for numerical fields can be reported using the module of quality of data. Besides, we apply predefined rules that make it easier to identify discrepant data value, which is quite important because the project has several variables. Several procedures guarantee the appropriate control of systematic errors (biases) and assure the methodological quality of the registry, amongst them:

- Successive sampling;

- Blinded evaluation of outcomes;

- Prevention of losses during the follow-up;

- Use of partial reports of quality of data;

- Use of electronic signature.

\section{Data management}

The Santa Maria University Hospital (SMUH) is responsible for the management of the data registry, whose information will be collected through electronic forms.

\section{System of data entry}

The data management will be accomplished using the REDCap (Research Electronic Data Capture) system. The case report forms (CRFs) will be transcribed through web medical records and will be included in a validation database.

\section{Case report form}

The study's CRFs will be filled out and sent through internet/intranet or web; the electronic signature is available through the access with a personal and non-transferable password.

\section{Data quality control}

For the quality control of the data, the following strategies are used:

- Training for data collection;

- Standard operational procedures handbook for each step of the protocol;

- Electronic CRF: aiming to prevent the occurrence of incomplete (mandatory data) or inconsistent data, or containing non-plausible values from the biological point of view;

- Central checking of data through statistical analysis to check possible inconsistencies;

- Quarterly reports of screening, recruiting, data quality, compliance to the protocol, consistency and filling out of collection forms.

\section{DISCUSSION}

The development and the implementation of the CardioCEC Registry were due to the need for identification of the outcomes from different techniques and equipment/materials used for cardiovascular surgical procedures. The planning of the database used variables recommended by interna- 
tional organizations, thus allowing the interoperability of the data ${ }^{12}$.

The involvement of the cardiovascular surgery multidisciplinary team through meetings and training favors the success of the registry's implementation. The assignment of distinct levels of access to each one of the members of the research team brings safety to the appropriate use of the database. The possibility of data tabulation in an offline environment in the REDCap mobile app favors the compliance ${ }^{16}$ to the filling out of the CardioCEC registry.

Mechanisms used to prevent systematic errors will be extensively studied. The branching logic used rendered more coherent and rational questionnaires ${ }^{14}$.

The automatized reports of data quality data give the researcher absolute control over the quality of the records made ${ }^{17}$.

\section{CONCLUSION}

The CardioCEC Registry is the first Brazilian electronic registry with several variables related to ECC, which are recommended by international repositories, allowing the interoperability between major national and international institutions, presenting relevant data in the conduction of the ECC in cardiovascular surgeries, as well as in the evaluation of the primary outcomes in this group of patients.

The registry has excellent potential for research in the field and allows for a significant contribution to the development of new technologies and innovations in the field of and cardiovascular surgery.

\section{Acknowledgment}

We thank the Registry Clinics Unit of the Institute of Cardiology / University Foundation of Cardiology of Rio Grande do Sul and the Santa Maria University Hospital.

\section{RESUMO}

OBJETIVO: Criar e implantar um registro clínico informatizado para verificar mortalidade e incidência de desfechos cirúrgicos maiores em pacientes adultos submetidos a cirurgias cardiovasculares a curto, médio e longo prazo.

METODOLOGIA: Trata-se de um estudo observacional do tipo Registro, prospectivo, que visa documentar as características dos pacientes submetidos à cirurgia cardiovascular.

RESULTADOS: As variáveis foram padronizadas de acordo com referências internacionais padronizadas pela The Society of Thoracic Surgeons (STS), American College of Cardiology (ACC), The Michigan Society of Thoracic and Cardiovascular Surgeons (MSTCVS) e o Departamento de Informática do SUS (Datasus). A padronização foi realizada na língua inglesa com uma interface em português para facilitar a coleta de dados na instituição. Serão mensurados indicadores de qualidade de atendimento, características do procedimento cirúrgico, além dos principais desfechos cardiovasculares. Os dados serão coletados durante a internação até a alta hospitalar ou até o sétimo dia, em 30 dias, seis meses, 12 meses e anualmente até completar cinco anos.

CONCLUSÃo: Evidenciou-se a importância da manutenção de banco de dados com padrões internacionais que podem ser reprodutíveis, possibilitando a avaliação de técnicas e assistência integrando os dados entre instituições de saúde.

PALAVRAS-CHAVE: Procedimentos cirúrgicos cardiovasculares. Base de dados. Registros eletrônicos de saúde.

\section{REFERENCES}

1. Ministério da Saúde, Departamento de Ciência e Tecnologia, Secretaria de Ciência, Tecnologia e Insumos Estratégicos. ELSA Brasil: maior estudo epidemiológico da América Latina. Rev Saúde Pública. 2009;43(1):1-2.

2. World Health Organization. Cardiovascular diseases (CVDs). [cited 2017 Jun 18]. Available from: http://www.who.int/en

3. Perk J, De Backer G, Gohlke H, Graham I, Reiner Z, Verschuren WM, et al. European guidelines on cardiovascular disease prevention in clinical practice (version 2012): the fifth joint task force of the European Society of Cardiology and other societies on cardiovascular disease prevention in clinical practice (constituted by representatives of nine societies and by invited experts). Int J Behav Med. 2012;19(4):403-88.

4. Piegas LS, Bittar OJNV, Haddad N. Cirurgia de revascularização miocárdica: resultados do Sistema Único de Saúde. Arq Bras Cardiol. 2009;93(5):55560.

5. Braile DM, Godoy MF. História da cirurgia cardíaca no mundo. Rev Bras Cir Cardiovasc. 2012;27(1):125-34.

6. Cavalcante RB, Pinheiro MMK, Watanabe YJÁ, Silva C). Grupo Técnico de Informação em Saúde e Populações: contribuições para a Política Nacio- nal de Informação e Informática em Saúde. Perspectivas em Ciência da Informação. 2015;20(1):92-119.

7. Pang X, Kozlowski N, Wu S, Jiang M, Huang Y, Mao P, et al. Construction and management of ARDS/sepsis registry with REDCap. I Thorac Dis. 2014;6(9):1293-9

8. Bodenheimer T, Grumbach K. Electronic technology: a spark to revitalize primary care? JAMA. 2003;290(2):259-64.

9. Majeed A. Ten ways to improve information technology in the NHS. BMJ. 2003;326(7382):202-6.

10. Snyder DC, Epps S, Beresford HF, Ennis C, Levens JS, Woody SK, et al. Research management team (RMT): a model for research support services at Duke University. Clin Transl Sci. 2012;5(6):464-9.

11. Obeid JS, Johnson LM, Stallings S, Eichmann D. Research Networking Systems: the state of adoption at institutions aiming to augment translational research infrastructure. J Transl Med Epidemiol. 2014;2(2):1026.

12. Anderson HV, Weintraub WS, Radford MJ, Kremers MS, Roe MT, Shaw RE, et al. Standardized cardiovascular data for clinical research, registries, and patient care: a report from the Data Standards Workgroup of the $\mathrm{Na-}$ 
tional Cardiovascular Research Infrastructure project. I Am Coll Cardiol. 2013;61(18):1835-46.

13. REDCap [Internet]. [cited 2017 Jun 18]. Available from: http://project-redcap.org/

14. REDCap [Internet]. [cited 2017 Jun 18]. Available from: https://projectredcap.org/wp-content/uploads/2016/08/CFRI-DM-REDCap-MobileApp-Manual.pdf
15. REDCap [Internet]. [cited 2017 Jun 18]. Available from: https://projectredcap.org

16. Dayer L, Heldenbrand S, Anderson P, Gubbins PO, Martin BC. Smartphone medication adherence apps: potential benefits to patients and providers. J Am Pharm Assoc (2003). 2013;53(2):172-81.

17. Lyon $\mid A$, Garcia-Milian R, Norton HF, Tennant MR. The use of Research Electronic Data Capture (REDCap) software to create a database of librarian-mediated searches. Med Ref Serv Q. 2014;33(3):241-52. 